\title{
Production procedure and marketing of ethnic fermented product Nga-pi in South-Eastern region of Bangladesh
}

\author{
MD. ISMAIL HOSSAIN, FATEMA HOQUE SHIKHA*, \\ QAMRUZZAMAN HOWLADER AND BIJOY KUMAR DAS \\ Department of Fisheries Technology \\ Bangladesh Agricultural University, Mymensingh 2202, Bangladesh \\ *Email: shikhafh@bau.edu.bd
}

\begin{abstract}
A survey was conducted to collect information on production procedure and marketing of Nga-pi in South-Eastern region of Bangladesh (Cox's Bazar and Bandarban). To collect information questionnaire was prepared, several visits were made, personal interview of different stakeholders were taken and audio-video recording was done. Socio-economic condition of different stakeholders of Nga-pi production and business showed that most of them were involved in Nga-pi production and business activities generation to generation. They are mostly people from Rakhine tribe and by religion they are Buddhist. Some of them, especially wholesalers are economically stronger than the producers or retailers. They have access to electricity, pure drinking water, sanitary latrines and most of them use cell phones for communication. The information on marketing channel of Nga-pi varies depending on the place, and season of the year. Generally, the whole seller and retailer get much profit than the Nga-pi producers. The survey results revealed that in the production procedure of Nga-pi in South-Eastern region (Cox's Bazar and Bandarban) have some points need to be improved to get better quality Nga-pi which may be stored for longer duration.

Key words: Nga-pi, Fermented product, Ethnic, Marketing
\end{abstract}

\section{Introduction}

Semi fermentation is being practiced to preserve small fishes specially puti (Puntius sp.) in Bangladesh. This product is similar to those prepared from marine fishes in other south-east Asian countries. Although there are differences in the detail preparation of the method of underlying principle is the same everywhere (Mansur et al. 1989). Major traditional fishery products of Bangladesh include dried, semi-fermented (chepa shutki/sheedal shutki), fermented, salted and some smoked products (BOBP 1985). Fermentation has been a popular technology for the preservation of fish in Southeast Asian countries from time immemorial. The Chinese used fermentation before the Christian era (NIIR Board of Consultants and Engineers 2003). Fermented fishery products are not produced commercial scale in Bangladesh. This types of fishery products are not popular in Bangladesh except, some Buddhist tribe (Rakhine) in Cox's Bazar, Barguna, Patuakhali, Chittagong and the districts of Chattagram Hill Tract. Some fermented products are also produced in Rangpur district for local consumption. The Rakhines prepare, eat and sell a fermented fish paste specialty product from fish or shrimp, called Nga-pi. Traditional fermented fish products are indigenous to southeast Asian countries such as Laos, Kampuchea, Vietnam, Thailand, Malaysia, Indonesia and Myanmar. Since the Rakhine have ancestry in Myanmar, Nga-pi had been with them as an integral part of their tradition and culture. With the migration from Myanmar traditional Nga-pi had also been brought with them. The versatility of Nga-pi is reflected in the colorful mosaic the people of Myanmar have developed to consume Nga-pi. Among various types of Nga-pies, Pè Nga-pi is used as both a flavoring and a condiment in Shan and Burmese cuisine. It may also be used to make a curry. 
In Bangladesh, the nutritional deficiency has become more acute because of tremendous rate of population growth without any significant increase in animal protein production. Millions of people are suffering from serious nutritional problem owing to acute storage of animal protein in their diet. Nga-pi production has a great potential in Bangladesh as because the production of $\mathrm{Nga-pi}$ needs less capital, the preparation procedure is easy and the raw materials, ingredients (salt) are available. Nowsad (2007) reported, raw material quality is not often maintained during shidhal or Nga-pi preparation. Local perception is that the spoilt shrimp can make Nga-pi as good as the fresh shrimp. Local people are often unable to differentiate between fish fermentation process and spoilage of fish. Sometimes, for special flavor development in some specialty Nga-pi products, ethnic consumers prefer certain level of spoilage of raw material. However, being a separate product, that should be done under complete control of the process where adequate levels of sanitation and hygiene have to be ensured. Therefore, the study was designed to collect information through a detailed survey on the production process and marketing of Nga-pi in Cox's Bazar region.

\section{Materials and Methods}

The research work was done by the collection of primary data from individual Nga-pi producers and traders. The primary data and information were collected regarding operation and activities involved in Nga-pi production.

Selection of study area: For this study, Cox's Bazar and Bandarban regions were selected. Among the 7 Upazillas, only Cox's Bazar Sadar Upazilla especially Chowfalldandi and Nazirartek drying yard is important for Nga-pi production due to the availability of drying yard, sunny place and cheap and abundant raw materials and labor. Therefore, Chowfalldandi Upazila was selected for the data collection from producer. On the other hand, the other area was selected for the study of wholesale and retail market was Bandarban district. Among the 7 Upazillas, only Bandarban Sadar is important for Nga-pi wholesaling and retailing because of the availability of wholesaler and retailer of Nga-pi and their consumer as Buddish, Christian and some Muslim people at that region.

Sample size: Survey was carried out among traditional Nga-pi producers, wholesalers and retailers from selected markets of Cox's Bazar and Bandarban area. A total of 2 retail markets, 2 wholesale markets and 2 production areas were surveyed of these two areas and relevant information obtained directly from 8 raw shrimp collectors, 16 Nga-pi producers, 12 wholesalers, and 10 retailers.

Survey and data collection from survey area: Data collection from selected survey areas was done using a pre-tested questionnaire, discussion with focus groups, observation by the team members and recording of audio-video recorder. Questionnaires were prepared according to the objectives of the study. To carry out survey on Nga-pi production, gathering different information related to Nga-pi preparation, collect information on socio-economic conditions of different stakeholders (producers, wholesalers and retailers) and marketing chain of Nga-pi, preparation of survey schedule is very important and needs expertise. In order to get a complete information on Nga-pi preparation and marketing chain of Cox's Bazar and Bandarban regions draft survey schedule was prepared and pre-tested. The draft schedule was modified and 
PRODUCTION AND MARKETING OF ETHNIC FERMENTED PRODUCT NGA-PI

improved on the basis of experience gained from the field. Finally, a set of items were listed and grouped in logical sequence of information designed to include both quantitative and monetary values of Nga-pi production.

The questionnaires mainly addressed the issues of $N g a-p i$ production procedure, different matters related to Nga-pi preparation, the socio- economic condition of producers, wholesalers, retailers and marketing information of Nga-pi. The questions of the interview schedule were open-ended; there were some closed questions as well with a number of alterative replies. Questionnaires were constructed in English and then translated into Bengali during face to-face interviews. During interview each question was explained clearly and asked systematically by the research team members for clear understanding to the interviewees and in some cases assistance from local guides also was taken.

Focus Group Discussion (FGD): For this study, participatory rural appraisal (PRA) tool such as, focus group discussion (FGD) was conducted with fishermen, Nga-pi producers and Nga-pi traders (3 group discussions with each separate groups). FGD was used to get an overview of abundance \& availability of shrimp species, total amount of shrimp catch, seasional variation of catch, production procedure of Nga-pi, marketing chain of shrimp and Nga-pi, income and particular issues. FGD held when fishermen and producers were free and where there was spontaneous gathering. First FGD was held in the yard of a Nga-pi producer at Daxin Rakhine para and another FGD was held in a tea stall along with retail market of Nga-pi in Bandarban town.

Recording by audio and video recorders: During interview tape-recorder and video camera were used whenever it was necessary for collection and saving data for more authenticity. After coming back to the laboratory, during data analysis the tape and video recorders were played (when required) to confirm the information gained from the study area.

\section{Results and Discussion}

Survey on Nga-pi production and socio-economic condition of different stakeholders: While going through a critical observation on the traditional processing of Nga-pi at Daxhin Rakhine para of Chowfalldandi of Cox's Bazar, several drawbacks have been identified. Plate 1 shows the different steps of Nga-pi preparation. It was found that the raw materials used for the preparation of Nga-pi was most of the time not fresh, although they used shrimp harvested on the same day (6-12 hours of harvest). These shrimps undergo spoilage rapidly if proper handling is not done on board immediately after hauling. Small shrimp coming from the boat was sometime mixed with dirt, sand, rubbish, algae (proper care is not taken to clean the shrimps), and secretion of entrails and rotten abdomen of fish. The material was directly taken on bamboo mat for processing without cleaning and washing. The shrimps were mixed with other species of fish, large shrimp, crabs, cephalopods and others unwanted mollusk and arthropods. The mats where the shrimp and ground paste are dried in the sun are not washed and cleaned after each operation. Solar salt used is of very low quality, deep-grayish in color, mostly impure and can serve as the source of contamination. The color of the traditional Nga-pi is not attractive.

During survey and FGD on the traditional Nga-pi production, some related information were collected (Table I). Mainly two species of small shrimps namely Asetes sp. and Mysid sp. 
are used in Nga-pi production. Quality deterioration of raw material is negligible at producer level and peak season of Nga-pi preparation is monsoon. About 2.5 to $5 \%$ salt is used during Nga-pi preparation but no chemical or preservative is used. For storage of raw material, no ice or cooling system is used at any level of Nga-pi production or sell. Nga-pi is produced mostly under tin shade on muddy floor, less labors are involved at this stage. Mainly Buddhist people of Rakhine tribe are involved in production and business of Nga-pi. Main problem in Nga-pi supply chain is communication and road problem. Good quality Nga-pi flavor is as like as salted hilsa and color is deep grayish.

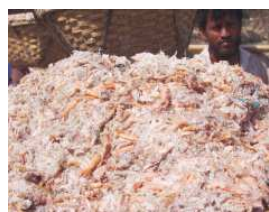

(a)

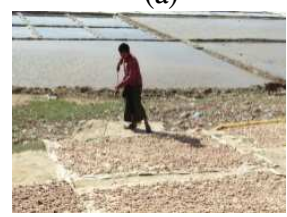

(f)

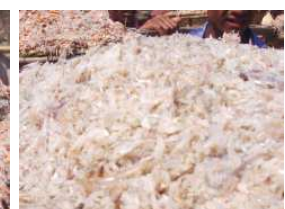

(b)

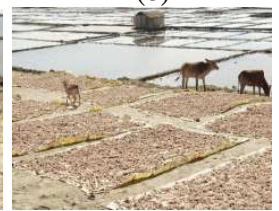

(g)

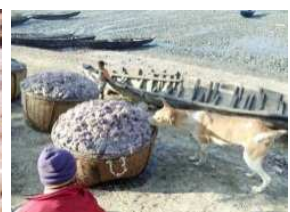

(c)

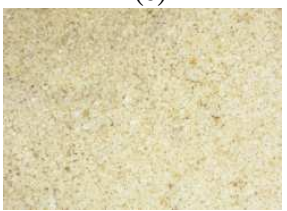

(h)

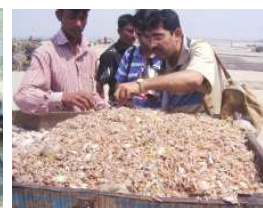

(d)

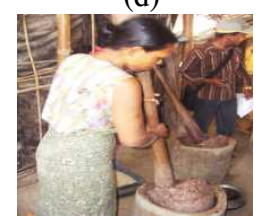

(i)

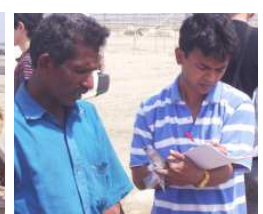

(e)

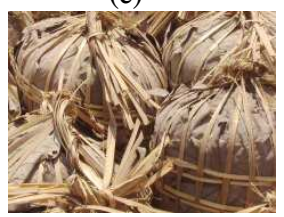

(i)

Plate 1. Production of Nga-pi at Cox's Bazar region (a) Asetes sp.; (b) Mysid sp.; (c) careless stock of harvested shrimp; (d) quality observation of raw material by the survey team; (e) questionnaire interview at raw material collection area; (f) spreading shrimp on mate for drying to prepare $N g a-p i$; (g) animal moving at drying yard of Nga-pi raw material indicating the lack of hygienic condition; (h) dried shrimp for Nga-pi preparation; (i) Rakhine lady preparing $\mathrm{Nga-pi}$; (j) prepared Nga-pi raped with mos pata and packed in bamboo basket for transportation

Tyn (1993) reported the technology of Nga-pi processing in Myanmar which is very similar to the process observed in south-eastern part of Bangladesh. The enzymatic fermentation of shrimp mediated by indigenous proteases yields short chain peptides and free amino acids which render the typical flavour and taste. Salt is added to prevent deterioration and food poisoning as well as to yield meaty-savoury flavor (Steinkraus 2002).

Socio-economic condition of different stakeholders: Survey was also carried out to collect information on the socio-economic condition of different stakeholders of Nga-pi production and sale at two different areas. The survey shows that-though different stakeholders are doing their job but many of them (producers, about $60 \%$, wholesalers, about $25 \%$ and retailers, about $20 \%$ ) do not have business ownership (Table II). Most of them are involved in production/business of $N g a-p i$ from generation to generation and they are economically stable. Due to involvement with this $\mathrm{Nga-pi}$ production/business they are sometimes despised and neglected in the society but some of them ignored the matter and become financially stronger. They belong to both single and joint family. The number of members of their family ranged from 4 to 12 persons per family. At producer level about $20 \%$ were single and about $80 \%$ were joint family. On the other hand about 55\% single and about $45 \%$ joint family pattern was found in wholesaler levels whereas at retail level the pattern was- about $70 \%$ single and about $30 \%$ joint family. Main 
income source of the families was Nga-pi production at producer level but at wholesaler or retailer level other income sources such as crops and vegetable cultivation, sewing, tuition etc.

Table I. Survey on related matters to Nga-pi production in Cox's Bazar and Bandarban areas

\begin{tabular}{|c|c|c|c|}
\hline \multirow[t]{2}{*}{ Major aspect } & \multicolumn{3}{|c|}{ Status /Description } \\
\hline & Producer & Wholesaler & Retailer \\
\hline $\begin{array}{l}\text { Raw materials collection } \\
\text { for } N g a \text {-pi production }\end{array}$ & From Fishermen & From producers & From wholesalers \\
\hline $\begin{array}{l}\text { Quality of shrimp/ } \\
\text { Nga-pi used (freshness) }\end{array}$ & Fresh & $\begin{array}{l}\text { Newly produced from } \\
\text { fresh materials }\end{array}$ & $\begin{array}{l}\text { Recently bought from } \\
\text { wholesaler }\end{array}$ \\
\hline Type of species used & $\begin{array}{l}\text { Small shrimp like Acetes } \\
\text { sp. and Mysid sp. of } \\
\text { shrimp which are locally } \\
\text { called ming \& maished } \\
\text { (respectively), sometimes } \\
\text { other small fishes too }\end{array}$ & -Do- & -Do- \\
\hline $\begin{array}{l}\text { Quantity of raw fish/ } \\
\text { Nga-pi loss }\end{array}$ & $1-2 \%$ of whole fish & Negligible & Negligible \\
\hline $\begin{array}{l}\text { Peak season of } \mathrm{Nga-pi} \\
\text { production, wholesaling } \\
\text { and retailing }\end{array}$ & $\begin{array}{c}\text { Monsoon season when } \\
\text { raw materials are very } \\
\text { available. }\end{array}$ & $\begin{array}{l}\text { Monsoon season when raw } \\
\text { materials are very } \\
\text { available \& enough } \mathrm{Nga-pi} \\
\text { were produced. }\end{array}$ & $\begin{array}{l}\text { Monsoon season when } \\
\text { raw materials are very } \\
\text { available \& enough } \mathrm{Nga} \text { - } \\
\text { pi were produced. }\end{array}$ \\
\hline $\begin{array}{l}\text { Quantity of salt used } \\
\text { during production }\end{array}$ & $2.5-5 \%$ salt & Not used & -Do- \\
\hline $\begin{array}{l}\text { Use of ice before } N g a-p i \\
\text { production wholesaling } \\
\text { and retailing, }\end{array}$ & No ice use & No refrigerator use & -Do- \\
\hline $\begin{array}{l}\text { Use of chemical/ } \\
\text { preservative }\end{array}$ & No chemical use & -Do- & -Do- \\
\hline $\begin{array}{l}\text { Major community involve } \\
\text { for } N g a-p i \text { production, } \\
\text { wholesaling and retailing }\end{array}$ & $\begin{array}{l}\text { Mainly Buddhist people of } \\
\text { Rakhine tribe }\end{array}$ & -Do- & -Do- \\
\hline $\begin{array}{l}\text { Labor involved for } \mathrm{Nga-pi} \\
\text { production, wholesaling } \\
\text { and retailing \& their } \\
\text { salaries }\end{array}$ & $\begin{array}{l}\text { Average } 3 \text { labors, their } \\
\text { salaries are 200Tk/day }\end{array}$ & No labors required. & -Do- \\
\hline $\begin{array}{l}\text { Structure of production, } \\
\text { wholesaling and retailing } \\
\text { house }\end{array}$ & $\begin{array}{l}\text { Tin shade with muddy } \\
\text { floor }\end{array}$ & $\begin{array}{l}\text { Building with concrete } \\
\text { floor }\end{array}$ & $\begin{array}{l}\text { Tin shed Building with } \\
\text { concrete floor }\end{array}$ \\
\hline $\begin{array}{l}\text { Characteristics of good } \\
\text { quality } N g a-p i\end{array}$ & $\begin{array}{l}\text { Flavor like salted hilsa } \\
\text { and color deep grayish }\end{array}$ & -Do- & -Do- \\
\hline$N g a-p i$ sold & To wholesaler and retailer & Retailers and consumers & Mainly local consumers \\
\hline Problem of Nga-pi supply & $\begin{array}{c}\text { Communication \& road } \\
\text { problem }\end{array}$ & $\begin{array}{c}\text { Lack of } \\
\text { telecommunication } \\
\text { facilities \& road problem }\end{array}$ & $\begin{array}{c}\text { Lack of } \\
\text { telecommunication } \\
\text { facilities \& road problem }\end{array}$ \\
\hline $\begin{array}{l}\text { Suggestion from producer, } \\
\text { wholesaler and retailer for } \\
\text { maintain good quality } \\
\text { (possible suggestions, if } \\
\text { they try) }\end{array}$ & $\begin{array}{c}\text { Use fresh and clean } \\
\text { shrimp } \\
\text { Drying of shrimp should } \\
\text { be done on elevated rack } \\
\text { Should use good quality } \\
\text { and clean salt } \\
\text { Keep hygienic condition }\end{array}$ & $\begin{array}{c}\text {-Do- } \\
\text {-Do- } \\
\text {-Do- } \\
\text {-Do- } \\
\text { Sorting dust \& undesirable } \\
\text { fish. }\end{array}$ & $\begin{array}{l}\text {-Do- } \\
\text {-Do- } \\
\text {-Do- } \\
\text {-Do- } \\
\text {.-Do- }\end{array}$ \\
\hline
\end{tabular}


MD. ISMAIL HOSSAIN et al.

Table II. Survey on socio-economic condition of different Nga-pi stakeholders in Cox's Bazar and Bandarban area

\begin{tabular}{|c|c|c|c|}
\hline \multirow[t]{2}{*}{ Major aspect } & \multicolumn{3}{|c|}{ Status/description } \\
\hline & Producer & Wholesaler & Retailer \\
\hline $\begin{array}{l}\text { Business ownership of } \\
N g a-p i\end{array}$ & $\begin{array}{c}\text { About } 60 \% \text { have no } \\
\text { ownership }\end{array}$ & $\begin{array}{c}\text { About } 25 \% \text { have no } \\
\text { ownership }\end{array}$ & $\begin{array}{c}\text { About } 20 \% \text { have no } \\
\text { ownership }\end{array}$ \\
\hline $\begin{array}{l}\text { Duration of involved in } \\
\text { this business }\end{array}$ & $\begin{array}{c}\text { Around } 35 \text { years } \\
\text { (generation to generation) }\end{array}$ & $\begin{array}{c}\text { Around } 33 \text { years } \\
\text { (generation to generation) }\end{array}$ & $\begin{array}{c}\text { Around } 40 \text { years } \\
\text { (generation to generation) }\end{array}$ \\
\hline $\begin{array}{l}\text { Reason of involvement } \\
\text { in this business }\end{array}$ & $\begin{array}{l}\text { Get from ancestors and } \\
\text { have benefits }\end{array}$ & -Do- & -Do- \\
\hline $\begin{array}{l}\text { Social status for getting } \\
\text { involvement in this } \\
\text { business }\end{array}$ & $\begin{array}{l}\text { Despised and neglected in } \\
\text { the society }\end{array}$ & $\begin{array}{l}\text { Despised and neglected in } \\
\text { the society / some of them } \\
\text { ignored the matter and } \\
\text { become financially strong }\end{array}$ & -Do- \\
\hline Family type & $\begin{array}{c}\text { About } 20 \% \text { Single and } \\
\text { about } 80 \% \text { joint family } \\
\text { pattern }\end{array}$ & $\begin{array}{c}\text { About } 55 \% \text { Single and } \\
\text { about } 45 \% \text { joint family } \\
\text { pattern }\end{array}$ & $\begin{array}{c}\text { About } 70 \% \text { Single and } \\
\text { about } 30 \% \text { joint family } \\
\text { pattern }\end{array}$ \\
\hline Total family members & $\begin{array}{c}4 \text { to } 6 \text { in single family and } \\
10 \text { to } 12 \text { members in joint } \\
\text { family }\end{array}$ & -Do- & -Do- \\
\hline Income source & $\begin{array}{l}\text { Almost } 100 \% \text { come from } \\
\text { this business; no other } \\
\text { income sources }\end{array}$ & $\begin{array}{l}\text { About } 70 \text { to } 75 \% \text { ) come } \\
\text { from this business; has } \\
\text { other income sources such } \\
\text { as crops and vegetable } \\
\text { cultivation }\end{array}$ & $\begin{array}{l}\text { About } 60 \text { to } 65 \% \text { ) came } \\
\text { from this business; has } \\
\text { other income sources as } \\
\text { crop and vegetable } \\
\text { cultivation, sewing at } \\
\text { home, tuition etc. }\end{array}$ \\
\hline Earning members & Self and other members & -Do- & -Do- \\
\hline Ownership of house & From ancestor/ Self & -Do- & -Do- \\
\hline Types of house & $\begin{array}{l}\text { Tin shade with muddy } \\
\text { floor }\end{array}$ & $\begin{array}{l}\text { Building with concrete } \\
\text { floor }\end{array}$ & $\begin{array}{l}\text { Tin shad /Building with } \\
\text { concrete floor }\end{array}$ \\
\hline Source of entertainment & Television and Radio & -Do- & -Do- \\
\hline Place of health care & Village health care center & $\begin{array}{c}\text { Sadar hospital \& private } \\
\text { health care center }\end{array}$ & -Do- \\
\hline Source of drinking water & $\begin{array}{l}\text { Deep tube wall which } \\
\text { established by World } \\
\text { Vision NGO }\end{array}$ & $\begin{array}{c}\text { Deep tube wall establishes } \\
\text { by local administration }\end{array}$ & -Do- \\
\hline Electricity facility & Present & -Do- & -Do- \\
\hline $\begin{array}{l}\text { Telecommunication for } \\
\text { business purpose }\end{array}$ & $\begin{array}{l}\text { Cell phone from fax-phone } \\
\text { shop/own cell phone }\end{array}$ & Mostly own cell phone & -Do- \\
\hline Sanitary latrine facility & $\begin{array}{l}\text { Mostly use sanitary latrine } \\
\text { which are facilitated by } \\
\text { World Vision and other } \\
\text { NGOs }\end{array}$ & Use sanitary latrine & -Do- \\
\hline Dowry payment status & $\begin{array}{c}\text { Mostly abhor dowry } \\
\text { payment and did not give } \\
\text { dowry }\end{array}$ & $\begin{array}{l}\text { Abhor dowry payment and } \\
\text { did not give dowry }\end{array}$ & -Do- \\
\hline
\end{tabular}

were observed. In some cases other family members also take part with head of the family in income generation. Most of the producers live in tin shade houses with muddy floor made by the ancestors, wholesalers live in building with concrete floor and retailers in tin shade house or in building with concrete floor build by ancestors/self/rental. All of the stakeholders have television and radio at their houses for entertainment and they use cell phones accept few 
PRODUCTION AND MARKETING OF ETHNIC FERMENTED PRODUCT NGA-PI

producers who use cell facilities available at nearby telecommunication shops. Electricity facilities are available every stakeholder's house and they get safe drinking water from deep tube well. At some producer's house deep tube wells were installed with the assistance of NGO (World Vision). World Vision and other NGOs supports in establishing sanitary latrines too at Nga-pi producing villagers. Other stakeholders also use sanitary latrines and they visit Sadar hospitals or nearby private health care centers the producers visit only village health care centers mostly. About dowry payment status it was observed that- most of the stakeholders abhor dowry payment and did not give dowry. Osman et al. (2016) carried out a study on the socio-economic conditions of the fishing community of Rezu khal in Ukhiya, Cox's bazar and Ahsan et al. (2016) studied the socio-economic condition of fishermen and intermediaries involved in marine fish marketing chain in Cox's Bazar area, Bangladesh. The observation in the present study on the socio-economic condition of different stakeholders of $\mathrm{Nga-pi}$ is quiet similar to the findings of the above cited researches.

Marketing chain of Nga-pi: Marketing is the connecting link between the producers and consumers. Through marketing system, the product reaches to the consumer in acceptable condition. The marketing system operated through a set of intermediaries performing useful commercial functions in a chain formation all the way from the producers to the final consumers. The study on the marketing system of traditional Nga-pi products shows that there is no specific marketing channel, it varies depending on the place and season of the year. Producers collect raw shrimp from fishermen who catch the shrimp in the sea belt. From the fishermen, the producers carry the shrimps by van or rickshaw to the processing area. Processors sell their Nga-pi to wholesalers. Then the wholesalers sell the products to the retailers which ultimately reach to its final destination the consumers (Fig. 1). The study indicated that- the participants of this study did not have licenses for Nga-pi business.

Studies were also conducted at production area, wholesaler and retail markets to know the supply and transportation status of traditionally produced Nga-pi at Cox's Bazar and Bandarban areas. The survey results shows that- from producer level Nga-pi is supplied to Chattagram, Rangamati, Bandarban, Ramu, Patuakhali region whereas from wholesaler Nga-pi is supplied to Chattagram, Rangamati, Patuakhali, and local consumers, recently to Nepal, India even (Table III). The results also shows that- in the business of Nga-pi no taxes are paid at any level and during excessive production of $\mathrm{Nga-pi}$ some time producers and wholesalers sell the product at minimum prize. For smooth running of business sometimes wholesalers and retailers take loan from different banks. The producers also need to take loan from banks, sometimes they take loan from wholesalers too. The rate of specific interest varies within $10-15 \%$ at different level for a certain time barrier. Though the producers do not have any license for their sell but wholesalers need to take trade license from district authorities and retailers need to take trade license from municipal corporations.

The survey result shows that- about $15 \%$ of the retailers purchase Nga-pi directly from producer and rest of the $85 \%$ of the retailers purchase Nga-pi directly from wholesalers of Bandarban area to reduce transportation problem (Table IV). Most of the wholesalers and retailers have business experience of over 30 to 50 years. The producers sell their products directly to the wholesalers of Chattagram, Rangamati, Bandarban, Ramu, and Patuakhali area to ensure maximum profit from this business whereas the wholesalers sell most of their products to the retailers of those areas and retailer sell their products to the local consumers. 


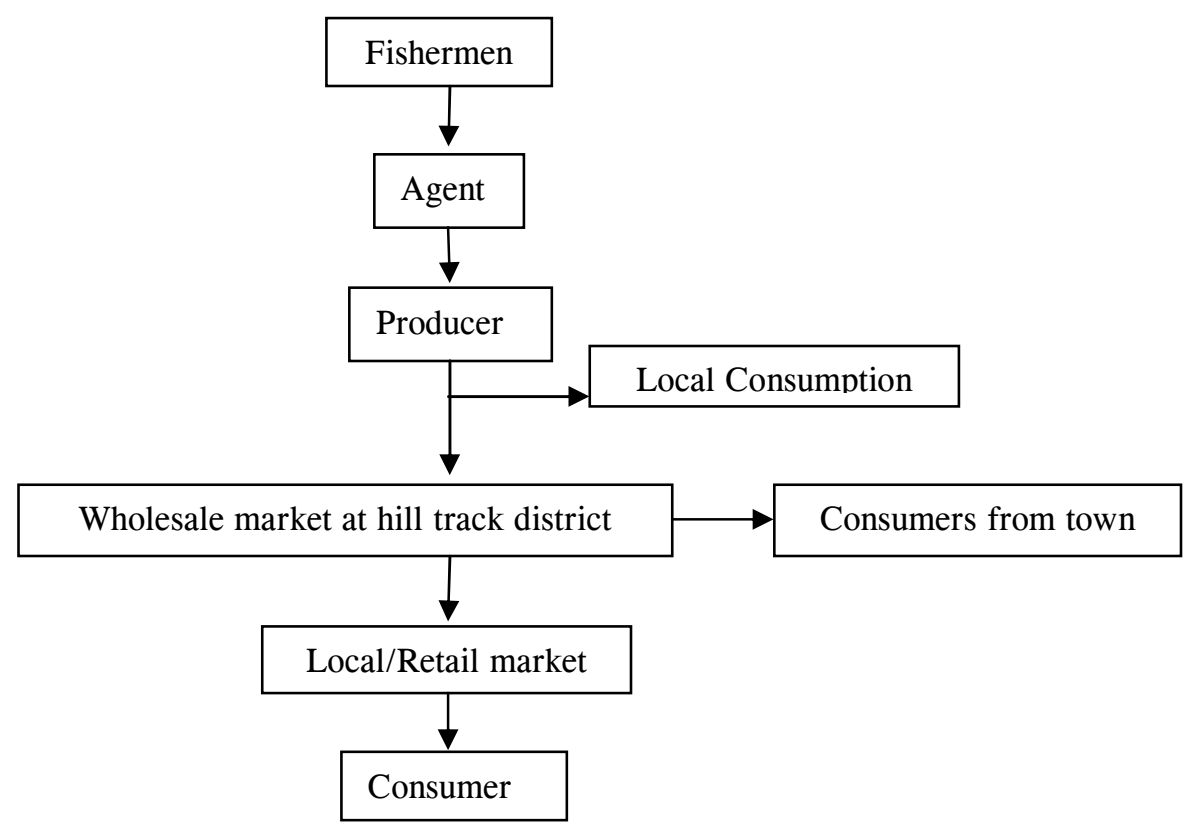

Fig. 1. Flow-chart showing the marketing chain of Nga-pi.

Table III. Survey result on Nga-pi supply and transportation at Cox's Bazar and Bandarban area

\begin{tabular}{|c|c|c|c|}
\hline \multirow[t]{2}{*}{ Major aspect } & \multicolumn{3}{|c|}{ Status / description } \\
\hline & Producer & Wholesaler & Retailer \\
\hline Marketing of $N g a-p i$ & $\begin{array}{l}\text { Producers sell their } \\
\text { products to the } \\
\text { wholesalers. }\end{array}$ & $\begin{array}{c}\text { Wholesalers sell their } \\
\text { products to the retailers and } \\
\text { consumers. }\end{array}$ & $\begin{array}{l}\text { Retailer sell their products to } \\
\text { the local consumers and other } \\
\text { consumers of the other cities. }\end{array}$ \\
\hline $\begin{array}{l}\text { Major Region of } \\
\text { Nga-pi supply }\end{array}$ & $\begin{array}{l}\text { Chittogonj, Rangamati, } \\
\text { Bandarban, Ramu, } \\
\text { Patuakhali etc. }\end{array}$ & $\begin{array}{l}\text { Chittogonj, Rangamati, } \\
\text { Patuakhali, even Nepal } \\
\text { India (recently) and local } \\
\text { consumer. }\end{array}$ & Mainly local consumer. \\
\hline $\begin{array}{l}\text { Tax for } \\
\text { transportation }\end{array}$ & No tax required & -Do- & -Do- \\
\hline $\begin{array}{l}\text { Marketing problem } \\
\text { for excess } \mathrm{Nga-pi} \text {. }\end{array}$ & To sell Nga-pi less price & -Do- & -Do- \\
\hline Loan taken from- & $\begin{array}{l}\text { Loan taken from } N g a-p i \\
\text { wholesalers, NGOs and } \\
\text { Govt. Bank. }\end{array}$ & $\begin{array}{c}\text { Loan taken from Govt. } \\
\text { Bank }\end{array}$ & $\begin{array}{l}\text { Loan taken from Govt. Bank } \\
\text { and NGOs }\end{array}$ \\
\hline $\begin{array}{l}\text { Condition for Loan } \\
\text { taken- }\end{array}$ & $\begin{array}{l}10 \% \text { interest within } \\
\text { specific time. }\end{array}$ & $\begin{array}{c}10-15 \% \text { specific interest } \\
\text { within } 2 / 3 \text { years. }\end{array}$ & $\begin{array}{c}10 \% \text { specific interest within } 2 / 3 \\
\text { years. }\end{array}$ \\
\hline $\begin{array}{l}\text { Need any license for } \\
\text { this business }\end{array}$ & No license required. & $\begin{array}{l}\text { Trade license required from } \\
\text { District. }\end{array}$ & $\begin{array}{l}\text { Trade license required from } \\
\text { municipal corporation. }\end{array}$ \\
\hline
\end{tabular}

The cost of production is more or less same round the year except that the raw material cost varies depending on the season and availability. Results show that, $40 \mathrm{~kg}$ first grade final product costs Tk.3000-3200 for raw material and for other expenses. A grade $40 \mathrm{~kg} \mathrm{Nga-pi} \mathrm{can}$ 
PRODUCTION AND MARKETING OF ETHNIC FERMENTED PRODUCT NGA-PI

be sold at Tk.3300-3700 by producers whereas the wholesalers can sell the products at Tk. $4000-4600$ per $40 \mathrm{~kg}$ and the retailers can sell at Tk.4700-5400 per $40 \mathrm{~kg}$. The result shows thatthe producer gets a profit margin of Tk. $300-500 / 40 \mathrm{~kg}$, Tk.700-900/40 kg by wholesalers Tk. $700-800 / 40 \mathrm{~kg}$ by retailers (Table IV).

Nayeem et al. (2010) conducted a survey the marketing system of traditional dried and semi-fermented fish product locally called "Chepa shutki" of Bangladesh. They found, there was no fixed marketing channel for those products and the length of marketing chain varied depending on location and season. Generally the processors collected raw materials from fishermen, middlemen or through a number of intermediaries, and processed the fish to sell them to wholesalers.

Table IV. Simple calculation of estimating the margin of $\mathrm{Nga-pi}$ production and business at Cox's Bazar and Bandarban area

\begin{tabular}{|c|c|c|c|}
\hline \multirow[t]{2}{*}{ Major aspect } & \multicolumn{3}{|c|}{ Status / description } \\
\hline & Producer & Wholesaler & Retailer \\
\hline Business capital & $\begin{array}{l}\text { Borrow from NGO and } \\
\text { money lander and Bank. }\end{array}$ & $\begin{array}{c}\text { Borrow from Govt. } \\
\text { bank. }\end{array}$ & $\begin{array}{l}\text { Borrow from Govt. bank } \\
\text { and NGO's. }\end{array}$ \\
\hline $\begin{array}{l}\text { Raw material/ Nga-pi } \\
\text { purchases at the price }\end{array}$ & $40 \mathrm{~kg}=\mathrm{Tk} \cdot 3,000-3,200$ & $40 \mathrm{~kg}=$ Tk. $3,300-3,700$ & $40 \mathrm{~kg}=$ Tk. $4,000-4,600$ \\
\hline$N g a-p i$ sold per $40 \mathrm{~kg}$ & $40 \mathrm{~kg}=$ Tk. $3,300-3,700$ & $40 \mathrm{~kg}=$ Tk. $4,000-4,600$ & $40 \mathrm{~kg}=$ Tk. $4,700-5,400$ \\
\hline Net profit per $40 \mathrm{~kg}$ & Tk. $300-500 / 40 \mathrm{~kg}$ & Tk. $700-900 / 40 \mathrm{~kg}$ & Tk. $700-800 / 40 \mathrm{~kg}$ \\
\hline $\begin{array}{l}N g a-p i \text { produced/ sold per } \\
\text { week ( } 7 \text { days) }\end{array}$ & $\begin{array}{c}60-70 \text { mounds } \\
(1 \text { maund }=40 \mathrm{~kg})\end{array}$ & $\begin{array}{c}30-35 \text { maunds } \\
(1 \text { maund }=40 \mathrm{~kg})\end{array}$ & $\begin{array}{c}\text { 4-4.5 maunds. } \\
(1 \text { maund }=40 \mathrm{~kg})\end{array}$ \\
\hline Net profit per week (7 days) & $18,000-35,000 \mathrm{Tk}$. & $70,000-100,000 \mathrm{Tk}$. & $2,800-3,600 \mathrm{Tk}$. \\
\hline
\end{tabular}

According to the report ILO, Myanmar (2016), three major existing and potential domestic markets for shrimp paste (Nga-pi) produced in Myeik: Yangon value-added processors; wet markets/home shops; supermarkets and mini marts. In addition, hotels, restaurants and souvenir shops provide further niche markets. Each have different consumers, requirements and likely trends for the future. The scale and level of sophistication of Yangon processors varies from the small-scale household level to sophisticated factory scale production. They have relatively high standards in terms of quality and food safety, due to the fact that their products are sold in higher-end retail outlets, which are fairly demanding.

\section{Conclusions}

The detailed survey carried out during this study showed that- different stakeholders are involved in Nga-pi production and business from generation to generation. Among them, wholesalers are economically stronger than producers or retailers. They have access to almost all kind of facilities necessary for livelihood. The marketing channel of $\mathrm{Nga}$-pi varies depending on the place and season of the year in Bangladesh. The result also revealed that- in the production procedure of $\mathrm{Nga-pi}$ at South-Eastern region (Cox's Bazar and Bandarban) have some points need to be improved to get better quality $N g a-p i$ which may be stored for longer duration and will ultimately contribute to expand the export opportunities of this kind of fishery products. 
Acknowledgment: This study was carried out with the financial support of Bangladesh Agricultural University Research System.

\section{Literature Cited}

Ahsan, M.K., N.S. Runa, S.K. Ghosh, M.M. Hasan and M. Kamal, 2016. Socio-economic condition of fishermen and intermediaries involved in marine fish marketing chain in Cox's Bazar area, Bangladesh. Asian J. Med. Biol. Res., 2 (1), 67-73; doi: 10.3329/ajmbr.v2i1.27571

BOBP., 1985. Marine small scale fisheries of Bangladesh: a general description, Madras, FAO Bay of Bengal Programme IV: $59 \mathrm{p}$.

Dillon, J.L. and J.B. Hardeker, 1999. Farm management research for small farmer development, FAO, Farm system manage. Series, 6: 302 p.

ILO, Myanmar. 2016. Processed seafood and mariculture value chain analysis and upgrading strategy: 913.

Mansur, M.A., S. Gheyasuddin and A.K.M.A. Bhuiyan, 1989. Preparation of a new- ready- use- dried semi-fermented fish product of increased shelf life from Puntius sp., Bangladesh. J. Fish., 12: 27-32.

Nayeem, M.A., K. Pervin, M.S. Reza, M.N.A. Khan, M.N. Islam and M. Kamal, 2010. Marketing system of traditional dried and semi-fermented fish product (Chepa shutki) and socio-economic condition of the retailers in local markets of Mymensingh region, Bangladesh. Bangladesh Res. Public J., 4(1): 69-75.

Needham, S. and S.J. Funge-Smith, 2014 "The consumption of fish and fish products in the Asia-Pacific region based on household surveys". FAO Regional Office for Asia and the Pacific, Bangkok, Thailand. RAP Publication 2015/12: 87 p.

NIIR Board of Consultants and Engineers, 2003. Handbook on Fisheries and Aquaculture Technology: 602 p.

Nowsad, A.A.K.M., 2007. Participatory Training of Trainers- A new approach applied in fish processing: $240 \mathrm{p}$.

Osman. M., M.S. Bhuyan, A. Akhtar, M.S. Islam, 2016. Socio-economic conditions of the fishing community of Rezu khalin Ukhiya, Cox's bazar. Discovery, 52(250): 1933-1946

Steinkraus, K.H., 2002. Fermentations in world food processing. Compr Rev Food Sci Food Safe, 1: 2332.

Tyn, M.T., 1993. Trends of Fermented Fish Technology in Burma. Fish Fermentation Technology (eds. C.H. Lee, K.H. Steinkraus and P.J.A. Reilly): 129-154. 